\title{
OBESITY IN CHILDHOOD AND ADOLESCENCE, GENETIC FACTORS
}

\author{
Marko Kostovski ${ }^{1}$, Velibor Tasic ${ }^{1}$, Nevena Laban ${ }^{1}$, Momir Polenakovic $^{2}$, Dragan Danilovski ${ }^{1}$, Zoran Gucev ${ }^{1}$
}

\author{
${ }^{1}$ Faculty of Medicine, University "Ss. Cyril and Methodius", 50 Divizija BB, 1000 Skopje, Republic of Macedonia \\ ${ }^{2}$ Macedonia Academy of Science and Arts, Skopje, Republic of Macedonia
}

Corresponding author: Marko Kostovski, Faculty of Medicine Skopje, 50 Divizija BB, 1000 Skopje, Macedonia, e-mail: marko.kostovski@medf.ukim.edu.mk

\section{ABSTRACT}

Obesity and excess weight are a pandemic phenomenon in the modern world. Childhood and adolescent obesity often ends up in obesity in adults. The costs of obesity and its consequences are staggering for any society, crippling for countries in development. Childhood obesity is also widespread in Macedonia. Metabolic syndrome, dyslipidemia and carbohydrate intolerance are found in significant numbers. Parents and grandparents are often obese. Some of the children are either dysmorphic, or slightly retarded. We have already described patients with Prader-Willi syndrome, Bardet-Biedl syndrome or WAGR syndrome. A genetic screening for mutations in monogenic obesity in children with early, rapid-onset or severe obesity, severe hyperphagia, hypogonadism, intestinal dysfunction, hypopigmentation of hair and skin, postprandial hypoglycaemia, diabetes insipidus, abnormal leptin level and coexistence of lean and obese siblings in the family discovers many genetic forms of obesity. There are about 30 monogenic forms of obesity. In addition, obesity is different in ethnic groups, and the types of monogenic obesity differ. In brief, an increasing number of genes and genetic mechanisms in children continue to be discovered. This sheds new light on the molecular mechanisms of obesity and potentially gives a target for new forms of treatment.

Keywords: obesity, children, adolescents, genetic causes

\section{INTRODUCTION}

Worldwide prevalence of obesity and childhood obesity is in constant and steep increase. Obesity has become pandemic. It affects at least 250 million people ( $7 \%$ of the estimated current world population), while at least 2-3 times more people are overweight [1].

Children are affected, too. $21-24 \%$ children and adolescents in USA are overweight and another $16-18 \%$ is obese. The prevalence of overweight children and adolescents in the United States has increased by $50-60 \%$ in a single generation, while the prevalence of obesity has doubled. Australia, Canada, France, Germany, Brazil, Chile, Finland, France, Germany, Greece, Japan, the UK, and the USA saw the prevalence doubled or tripled between the early 1970s and late 1990s [1, 2].

There is an ethnic and racial difference in the prevalence of obesity. In American Indians, 
Hispanics, Hawaiians, Hispanics, and blacks obesity is $10-40 \%$ higher than in whites [3]. Moreover, the majority of adults in some societies are overweight. In the United States, 61 percent of all adults are overweight. In Russia, the figure is 54 percent; in the United Kingdom 51 percent; and in Germany 50 percent. For Europe as a whole, more than half of those between 35 and 65 years of age are overweight $[1,2]$.

It is of note that the adolescent obesity is predictive of adult obesity: $80 \%$ of teenagers who are obese continue on to be obese as adults. The prevalence of obesity is high in Macedonia, too [4]. There is also a sign of hope: the 2006 review suggests that the increase in childhood obesity in the USA, the UK, and Sweden might be abating $[5,6,7]$.

This explosion of obesity is probably a result of historical convergence. Early on humans with parsimonious caloric intake had a biological advantage as food was scarce and starvation common. Later one, this "thrifty gene" was massively challenged by the abundance of food in most of the developed world.

Obesity is costly for any society: some estimates suggest that the management of obesity in the USA costs approximately $\$ 100$ billion yearly.

\section{Criteria}

In children, effects of age, sex, puberty, and race or ethnicity on growth make classification difficult. Methods based on weight, weightheight, skinfold thickness have advantages and disadvantages. The World Health Organization (WHO) bases its criteria for obesity in childhood and adolescence on BMI. BMI that is greater than the 85th (overweight) or the 95th (obesity) percentile, for age-matched and sex-matched control subjects. Overweight, obese, and morbidly obese refer to children and adolescents whose weights exceed those expected for heights by $20 \%, 50 \%$, and $80-100 \%$, respectively.

The International Obesity Taskforce (IOTF) international standard growth chart enables global comparison of prevalence [8]. Many countries continue to use their own country-specific charts [9]. The dominantly used thresholds for being overweight or obese in childhood are: $110 \%$ or $120 \%$ of ideal weight for height; weight-for-height $\mathrm{Z}$ scores of higher than 1 or higher than 2 , and BMI at the 85th, 90th, 95th, and 97th percentiles (on the basis of international or country specific reference populations). It is of note that, the IOTF classification has high specificity, but low sensitivity [10].

There is a modification of those criteria for adults: grade 1 overweight (overweight) is a BMI of $25-29.9 \mathrm{~kg} / \mathrm{m} 2$, grade 2 overweight (obesity) is a BMI of $30-39.9 \mathrm{~kg} / \mathrm{m} 2$ and grade 3 overweight (severe or morbid obesity) is a BMI greater than or equal to $40 \mathrm{~kg} / \mathrm{m} 2$. In addition, there are surgical definitions which describe BMI greater than 40 $\mathrm{kg} / \mathrm{m} 2$ as severe obesity, a BMI of $40-50 \mathrm{~kg} / \mathrm{m} 2$ is termed morbid obesity, and a BMI greater than $50 \mathrm{~kg} / \mathrm{m} 2$ is termed super obese.

\section{Pathophysiology}

This is an energy imbalance between excessive energy intake and/or reduced energy expenditure. Sedentary lifestyle with excessive television viewing and/or excessive computer use coupled with insufficient physical activity results in obesity in children and adolescents. In infancy, excess fat deposition occurs when excess energy is provided, especially when the protein-to-energy ratio is altered. Excess weight in children depends on both genetic and environmental factors.

Etiological factors are many. As much as $>90 \%$ of cases are idiopathic, $<10 \%$ are associated with hormonal or genetic causes [1]. Hormonal disorders: growth hormone deficiency and growth hormone resistance, hypothyroidism, leptin deficiency or resistance to leptin action $[11,12$, 13], glucocorticoid excess (Cushing syndrome), prolactin-secreting tumors, precocious puberty, polycystic ovary syndrome (PCOS) all can be manifested with obesity. Some medications cause excess weight/obesity: glucocorticoids, oral contraceptives, insulin, sulfonylureas, risperidone, thiazolidinediones, clozapine, tricyclic antidepressants, monoamine oxidase inhibitors (MAOIs: e.g phenelzine).

\section{Other causes}

Inflammatory and infective etiology may exist for obesity: adenovirus 36 infection is associated with obesity in chickens and mice. In humans, those who are not obese have a 5\% prevalence of adenovirus 36 infection, while those who are obese have a prevalence of $20-30 \%$. 


\section{MENDELIAN OBESITY}

Mendelian pattern of inheritance is observed in some types of obesity [14].

\section{Syndromic monogenic obesity}

Syndromic monogenic obesity is rare and featuring obesity and mental retardation, dysmorphic features and organ-specific abnormalities [14].

Prader-Willi syndrome (PWS), has an incidence of 1 in 15000-30000 [15]. Patients have hypotonia, feeding difficulties, poor growth and delayed development in the first year of life. Later, patients develop hyperphagia, childhood obesity, short stature and cognitive disability [15].

In PWS only the paternal gene copies are expressed [16]. Paternal deletions are found in $65-75 \%$ of the patients [17], while maternal uniparental disomy is found in 20-30\% [17]. In 1-3\% of the patients there are imprinting defects, caused by epimutations or incomplete processing of the imprint from the father or from microdeletions in the DNA imprinting centre [17]. Several genes are implicated with PWS: makorin ring finger protein 3 (MKRN3), Necdin (NDN), nuclear pore associated protein 1 (NPAP1), SNRPN upstream reading frame (SNURFSNRPN), MAGE family member L2 (MAGEL2), and 5 small nucleolar RNA [18, 19, 20, 21, 22, 23].

Bardet-Biedl syndrome (BBS) is an autosomal recessive ciliopathy with retinal degeneration, polydactyly cognitive disability, and genital and renal anomalies [24]. Obesity occurs mostly in the early years of life and sometimes results in T2D [25]. There are at least 19 BBS genes [18, 19, 20, $26]$. Interestingly the BBS proteins mediate leptin receptor (LEPR) signaling [27]. It has been suggested that children with BBS at the initial work up should undertake imaging studies of the kidney and urinary tract. Also, in order to prevent endstage renal disease (ESRD), close renal follow up from an early age of life is proposed [28].

Alstrom syndrome is a ciliopathy recessively inherited [29], with retinal dystrophy, hearing impairments, early-onset obesity, insulin resistance (IR) and T2D [30]. There are only 300 known cases so far [29]. Mutations in Alstrom syndrome protein 1 (ALMS1) were found in six unrelated families [31].
Albright hereditary osteodystrophy (AHO), or pseudohypoparathyroidism Ia, is an autosomal dominant disorder with clinical features of hyperphagia, obesity, mental retardation, short stature, round facies and skeletal anomalies [32]. AHO is caused by the mutations in the guanine nucleotide binding the alpha-sub-unit of the stimulatory $\mathrm{G}$ protein $(\mathrm{Gs} \alpha)$. It mediates the actions of hormones, neurotransmitters and paracrine/autocrine factors [33], resulting in resistance to the parathyroid hormone, thyroid stimulating hormone and gonadotropins [34].

Cohen syndrome, or obesity-hypotonia syndrome has characteristic facial features, microcephaly, hypotonia, non-progressive psychomotor retardation, motor clumsiness, progressive myopia and truncal obesity [35]. This is an autosomal recessive disorder caused by mutations in the Cohen 1 (COH1/VPS13B) gene [36].

Kabuki syndrome is characterized by specific face, mental retardation, visceral and skeletal malformations, growth deficiency, obesity and endocrinological anomalies [37]. Heterozygous mutations in the gene lysine (K)-specific methyltransferase 2D (KMT2D/MLL2) as the cause of Kabuki syndrome in $56-76 \%$ of the cases $[38,39$, 40]. Infrequently, the syndrome has been linked to a mutation in the lysine (K)-specific demethylase 6A (KDM6A) gene [39].

Borjeson-Forssman-Lehmann (BFL) is characterized with severe mental disability, microcephaly, epilepsy, hypogonadism, obesity and gynecomastia [41]. This is an X linked disorder, caused by the mutations in the PHD finger protein 6 (PHF6) gene [42]. Not all patients carry mutations in PHF6.

Carpenter syndrome, or acrocephalopolysyndactyly type II, is characterized with acrocephaly, preaxial polydactyly, soft tissue syndactyly, brachy- or agenesis mesophalangy of the hands and feet, congenital heart disease, hypogenitalism, obesity, umbilical hernia and mental retardation [43]. This is an autosomal recessive disorder, caused by the mutations in the RAB23 gene [44, 45].

Smith-Magenis syndrome (SMS) is a neuro-behavioral disorder characterized with obesity, sleep disturbance and multiple developmental anomalies [46]. This is an autosomal dominant disorder caused by heterozygous mutations in retinoic acid induced 1 (RAI1) gene.

Wilms tumour, aniridia, genitourinary abnormalities and mental retardation (WAGR) syn- 
drome is caused by $11 \mathrm{p} 13$ deletions [47]. Obesity has been observed in approximately $30 \%$ of WAGR patients [48]. Most of obese WAGR patients have altered brain-derived neurotrophic factor (BDNF) gene [47]. Fluorescence in situ hybridization (FISH) study of a 8.5 year-old girl revealed a deletion of the WT1 and PAX6 gene in the 11p13 WAGR region [49].

\section{NON-SYNDROMIC} MONOGENIC OBESITY

Non-syndromic monogenic obesity refers to a single gene disorder.

Leptin. A mutation in the leptin (LEP) gene with truncated transcription of leptin was described in two severely obese cousins within a highly consanguineous family of Pakistani origin [50]. Other reports followed describing patients with no detectable leptin, in Pakistan, Turkey and Egypt $[51,52]$. The patients with a homozygous LEP mutation had detectable circulating leptin levels, indicating the existence of a bio-inactive leptin protein [53].

LEPR deficiencies were found in severely obese siblings [54], in patients with severe early-onset obesity with mutations in LEPR [55], having high serum levels of leptin which indicated receptor insensitivity [55]. Further reports found Pakistani patients [56], patients in French population from Reunion Island [57].

Patients with mutations in LEP or LEPR had severe hyperphagia, rapid weight gain within the first year of life, and intolerant behavior when food restrictions were demanded [58]. Hypo-gonadotrophic hypogonadism is frequent [55]. Those children have defective T-cell mediated immunity, with high rates of infection and mortality [55]. Strikingly, loss-of-function mutations in LEP and LEPR have low blood pressure, despite obesity [59].

Leptin treatment in a girl with leptin deficiency resulted in weight reduction, reduced energy intake and increase in gonadotropin concentrations [60].

Loss-of-function mutations in SH2B1 an regulator of leptin, led to severe early-onset obesity, hyperphagia, IR, reduced height and behavioral abnormalities [61].

Proopiomelanocortin (POMC) deficiency in humans has the following characteristics: obesity, adrenal insufficiency, red hair, skin hypopigmentation, neonatal hypoglycemia, seizures, cholestasis and voracious appetite $[62,63,64]$. Severe motor and mental retardation was also reported [65].

Deficiency in prohormone convertase 1 (PC1/3), results in early-onset obesity, hyperphagia, postprandial hypoglycemia and other endocrine dysfunction. The main reason is that its role in the cleavage of proinsulin into insulin and POMC into alpha-melanocyte-stimulating hormone $(\alpha-\mathrm{MSH})$ is lacking $[66,67,68]$. Null mutations have diarrhea and diabetes insipidus $[66,68,69,70,71]$, while a nonsense loss-of-function mutation at the heterozygous state causes familial obesity associated with glucose intolerance/diabetes [72].

Melanocortin 4 receptor (MC4R) mutations cause autosomal dominant obesity. It is of note that not all heterozygous carriers of MC4R become obese, but homozygous all have early-onset obesity [73]. MC4R deficient patients display hyperinsulinemia, increased linear growth, and an increase in bone mass in both children and adults $[74,75,76]$. Additionally, patients experience an increase in both fat and lean mass, which is not observed in other forms of monogenic obesity [77].

The neurotrophic tyrosine kinase receptor type 2 (NTRK2) missense mutation was found in a boy with early-onset obesity, hyperphagia, developmental delay, impairment in short-term memory and impaired nociception [78]. There was an alteration of the BDNF stimulated protein kinase phosphorylation, too [78]. In addition, loss of one functional copy of BDNF manifested hyperphagia, severe obesity, cognitive impairment and hyperactivity [79].

Single-minded homologue 1 (SIM1) has an essential role in formation of the paraventricular nucleus (PVN) of the hypothalamus [80, 81]. SIM1 haploinsufficiency leads to hyperphagia, obesity and reduction in the PVN [82]. SIM1 haploinsufficiency led to excessive growth, severe early-onset obesity [83]. Heterozygous deleterious mutations in SIM1 were observed in obese children with additional Prader-Willi-like neurobehavioral features $[84,85,86]$.

KSR2 loss-of-function mutations were found in patients with hyperphagia, early-onset obesity, low heart rate, reduced basal metabolic rate and severe IR [87]. Mutations in Tubby bipartite transcription factor (TUB) were observed in patients with deteriorating vision, obesity and normal lucose/cholesterol/triacylglycerol levels [88]. 


\section{OLIGOGENIC OBESITY}

In contrast to monogenic obesity which is rare, obesity in humans carrying heterozygous deleterious coding mutations in these genes is significantly more frequent but not fully penetrant [89]. Based on loss-of-function mutation frequency of MC4R in the population of United States (US) $(0.07 \%), 426701$ heterozygous MC4R carriers compared with 149 homozygous carriers $(\mathrm{N}$ $=305000000)$ are probable. Partial MC4R deficiency may explain obesity in 256021 individuals, whereas complete MC4R deficiency may be the cause of obesity for only 149 subjects in the US population [90]. Those humans have also interaction with "obesogenic" environment [91, 92]. In different ethnic communities there is a prevalence of $0.2-5.6 \%$ of MC4R heterozygous, heterozygous compound and homozygous lossof-function mutation carriers [73].

The same is true for the heterozygous lossof-function mutations in POMC which result in a non-fully penetrant form of obesity 93, 94, 95]. Partial deficiency of LEP and LEPR has been found in humans with a higher percentage of body fat mass $[55,96]$.

\section{POLYGENIC OBESITY}

In polygenic obesity multiple gene defects interact with the environment [97] e.g. A three SNP haplotype in ectonucleotide pyrophosphatase/phosphodiesterase 1 (ENPP1) was found to contribute to childhood and adult obesity in a recessive model in European populations [98, 99]. K121Q has also been associated with adult obesity in European populations [100].

Since the discovery of FTO, many other loci that contribute to BMI, adult obesity, childhood obesity have been identified [101, 102, 103, 104]. GWAS have identified 135 variants associated with BMI level and/or obesity status. SNPs in most Mendelian non-syndromic genes (BDNF, NTRK2, LEPR, MC4R,PCSK1, POMC, SH2B1, TUB) and some Mendelian syndromic genes (SDCCAG8, BBS4) have been proven to play role in polygenic obesity.

\section{FROM GENOMICS TO CLINICAL PRACTICE}

Strikingly, the US Supreme Court considers gene patenting as illegal [105]. However, some patents are still active, so identifying mutations must be done within a legal framework, using expensive patented genetic tests instead of whole genome/exome sequencing experiments [106, 107].

In children, no evidence was found for effects of 12 GWAS-based obesity marker alleles on weight regain [108], and only the FTO common variants [109] were associated with weight regain. However, these findings await further confirmation, and highlight the challenges of replicating genediet interactions in randomized clinical trials [110].

Case reports on carriers of homozygous LEPR and MC4R mutations showed lower weight loss and poorer outcomes after bariatric surgery $[111,112]$. A more complex relationship has been reported for heterozygous MC4R mutations, showing no significant effects on bariatric surgery outcomes $[112,113]$. In a study matching carriers of functional MC4R mutations or MC4Rvariants and two randomly paired controls without mutations, no difference in weight loss was observed [114], however, the design of functional characterization of mutations and variants was questionable [115]. Carriers of rare variants of MC4R matched with the MC4R reference allele carriers also demonstrated comparable weight loss [116]. In the Swedish Obesity Study, FTO was associated with maximum weight loss in gastric banding surgery subjects but not in gastric bypass subjects [117]. GWAS of gastric bypass subjects found that the $15 \mathrm{q} 26.1$ locus was significantly associated with weight loss [118]. However, larger studies, longitudinal analyses, and subsequent meta-analyses comprising of not only the genome, but also the epigenome and metagenome, are required to definitively establish whether treatment outcomes can be improved through assignment of patients to personalized surgical techniques.

The multifactorial origin of obesity gives rise to a variable response to anti-obesity medication, suggesting that efficacy of all new centrally active anti-obesity drugs [119] should be carefully assessed 
by using genomic information to ensure proper prescription and dispensing, in order to avoid unnecessary and potentially life-threatening side effects [120]. Identifying biomarkers for the development of diagnostics to guide prescriptions carries the potential of reducing adverse drug reactions and improving outcomes, while saving the healthcare system and patients from ineffective prescriptions.

\section{CO-MORBIDITIES} AND COMPLICATIONS

Obesity has a considerable impact on life quality, and some reduce life expectancy. Being overweight or obese between ages 14 and 19 years was associated with increased adult mortality (from age 30 years) from various systemic diseases [121]. Co-morbidities and complications are severe:

1. Cardiovascular: essential hypertension, coronary artery disease, left ventricular hypertrophy, cor pulmonale, cardiomyopathy, accelerated atherosclerosis, pulmonary hypertension. CNS: stroke, idiopathic intracranial hypertension, meralgia paresthetica.

2. Respiratory: obstructive sleep apnea, Pickwickian syndrome), increased predisposition to respiratory infections, increased incidence of bronchial asthma.

3. GI: cholecystitis, cholelithiasis, steatohepatitis, fatty liver infiltration, reflux esophagitis.

4. Malignant: association with 11 types of common human cancer are well established: endometrial, prostate, gallbladder, breast, colon, lung cancer.

5. Orthopedic: osteoarthritis, coxa vera, slipped capital femoral epiphyses, Blount disease and Legg-Calvé-Perthes disease, lumbago. Tibia vara (Blount's disease) [122], slipped capital femoral epiphyses [123]. Alterations in the FTO gene, suggested that high-fat mass in children was associated with increased [124].

6. Metabolic: insulin resistance, hyperinsulinemia, type 2 diabetes mellitus, dyslipidemia. The rate of increase in BMI during adolescence may be a significant risk factor for diabetes [125, 126]. About half of the children with BMI higher than the 97th percentile have one or more of the disorders that make up the metabolic syndrome [127].
7. Reproductive: anovulation, early puberty, infertility, hyperandrogenism and polycystic ovaries in women, hypogonadotropic hypogonadism in men. There is an acceleration in timing of the larche and menarche in girls [128, 129], pubertal advancement in boys [130] and adverse effects on maturation [131] and alignment [132] of developing bones in both sexes. The advanced skeletal maturation has been attributed to increased adipose tissue aromatization. Pubertal timing might be altered by nutrition-related signals (eg, insulin and leptin) [133].

8. Obstetric and perinatal: pregnancy-related hypertension, fetal macrosomia, pelvic dystocia.

9. Surgical: increased surgical risk and postoperative complications.

10. Psychologic: social isolation, peer problems, depression.

11. Miscellaneous: reduced mobility, difficulty maintaining personal hygiene, Stress incontinence, Intertrigo (bacterial and/or fungal), acanthosis nigricans, hirsutism, increased risk for cellulitis and carbuncles, venous varicosities, lower extremity venous and/or lymphatic edema.

\section{TREATMENT}

The team approach to therapy (nurse educators, nutritionists, exercise physiologists, and counselors) is essential [134]. Family-based behavioral weight control is effective [135]. Physical activity should be encouraged and time spent watching television and playing computer games reduced. The quantity and the content of daily meals should be adjusted: less sugars, more vegetables and fruit. Improving fitness in children correlates with a lower incidence of obesity in adolescence [136]. The severe controlled-energy diets is not fit for children and adolescents.

Medication. Sibutramine may be classified as an anorectic drug, whereas orlistat's $[18,19]$ mechanism of action involves induction of lipid maldigestion. A randomized placebo-controlled trial of sibutramine in adolescents resulted in a significant reduction in body mass index (BMI), without [20]. Benzphetamine (Didrex), phendimetrazine (Bontril), diethylpropion, and phentermine (Ionamin) have also been used.

Rhythm Pharmaceuticals (ESPE 2016) presented preliminary results from a phase $1 \mathrm{~b}$ clin- 
ical trial assessing the safety and efficiency of setmelanotide (RM-493), an MC4R agonist, in obese patients with a heterozygous genetic defect in MC4R. Patients lost weight and the treatment was well tolerated. The same company is now extending the clinical trial to patients with monogenic obesity mutations in POMC (ESPE 2016).

Surgical Care. Various bariatric surgical procedures have been used in some adolescents [137]. Usual criteria include patients $>15 \mathrm{y}$, with a BMI of more than 40 or weight exceeding $100 \%$ of ideal body weight (IBW).

In the vertical-banded gastroplasty (VBG), a pouch of $15-\mathrm{mL}$ to $30-\mathrm{mL}$ capacity is constructed, greatly reducing the amount of food that can be eaten. In gastric bypass, a larger pouch that empties into the jejunum is created [138]. Laparoscopic placement of an adjustable gastric band (LAGB) has supplanted the vertical-banded gastroplasty as safer and reversible. LAGB positions a collar with an internal, saline-filled balloon around the upper stomach [139].

\section{REFERENCES}

1. Memedi R, Tasic V, Nikolic E, Jancevska A, Gucev Z. Obesity in childhood and adolescence, genetic factors. Pril (Makedon Akad Nauk Umet Odd Med Nauki). 2013;34(2):85-89.

2. Wang Y, Lobstein T. Worldwide trends in childhood overweight and obesity. Int J Pediatr Obes. 2006;1(1):11-25.

3. Ebbeling CB, Pawlak DB, Ludwig DS. Childhood obesity: publichealth crisis, common sense cure. Lancet. 2002;360(9331):473-482.

4. Krstevska-Konstantinova M, Jancevska A, Kocova M, Gucev Z. Weight, height and puberty in a cohort of Macedonian girls. Med Arh. 2009;63(2):80-1.

5. Ogden CL, Carroll MD, Flegal KM. High body mass index for age among US children and adolescents, 2003-2006. JAMA. 2008;299(20):24012405.

6. Kipping RR, Jago R, Lawlor DA. Obesity in children. Part 1: epidemiology, measurement, risk factors, and screening. BMJ. 2008;337:a1824.

7. Sundblom E, Petzold M, Rasmussen F, Callmer E, Lissner L. Childhood overweight and obesity prevalences levelling off in Stockholm but socioeconomic diff erences persist. Int J Obes (Lond). 2008;32(10):1525-1530.
8. Cole TJ, Bellizzi MC, Flegal KM, Dietz WH. Establishing a standard defi nition for child overweight and obesity worldwide: international survey. BMJ. 2000;320(7244):1240-1243.

9. Troiano RP, Flegal KM, Kuczmarski RJ, Campbell SM, Johnson CL. Overweight prevalence and trends for children and adolescents. The national health and nutrition examination surveys, 1963 to 1991. Arch Pediatr Adolesc Med. 1995;149(10):1085-1091.

10. Neovius MG, Linne YM, Barkeling BS, Rossner SO. Sensitivity and specifi city of classifi cation systems for fatness in adolescents. Am J Clin Nutr. 2004;80(3):597-603.

11. Unger RH. The hyperleptinemia of obesity regulator of caloric surpluses. Cell. 2004;117(2):145146.

12. Montague CT, Farooqi IS, Whitehead JP, et al. Congenital leptin deficiency is associated with severe early-onset obesity in humans. Nature. 1997;387(6636):903-1103.

13. Farooqi IS, Matarese G, Lord GM, et al. Beneficial effects of leptin on obesity, T-cell hyporesponsivness, and neuroendocrine/metabolic dysfunction of human congenital leptin deficiency. J Clin Invest. 2002;110(8):1093-1103.

14. Waalen, J. The genetics of human obesity. Trans1 Res. 2014;164(4):293-301.

15. Cassidy SB, Driscoll DJ. Prader-Willi syndrome. Eur J Hum Genet. 2009;17(1):3-13.

16. Butler, MG. Prader-Willi syndrome: obesity due to genomic imprinting. Curr Genomics. 2011;12(3):204-215.

17. Angulo MA, Butler MG, Cataletto ME. Prader-Willi syndrome: a review of clinical, genetic, and endocrine findings. J Endocrinol Invest. 2015;38:1249-1263.

18. Sahoo T, Gaudio D, German JR, et al. Prader-Willi phenotype caused by paternal deficiency for the HBII-85 C/D box small nucleolar RNA cluster. Nat Genet. 2008;40(6):719-721.

19. Jong MT, Carey AH, Caldwell KA, et al. Imprinting of a RING zinc-finger encoding gene in the mouse chromosome region homologous to the Prader-Willi syndrome genetic region. Hum Mol Genet. 1999;8(5):795-803.

20. Boccaccio I, Glatt-Deeley H, Watrin F, Roeckel N, Lalande M, Muscatelli F. The human MAGEL2 gene and its mouse homologue are paternally expressed and mapped to the Prader-Willi region. Hum Mol Genet. 1999;8(13):2497-2505.

21. MacDonald HR, Wevrick R. The necdin gene is deleted in Prader-Willi syndrome and is imprinted in human and mouse. Hum Mol Genet. 1997;6(11):1873-1878. 
22. Farber C, Gross S, Neesen J. Buiting K. Horsthemke B. Identification of a testis-specific gene (C15orf2) in the Prader-Willi syndrome region on chromosome 15. Genomics. 2000;65(2):174-183.

23. Griggs J, Sinnayah P, Mathai, ML. Prader-Willi syndrome: from genetics to behaviour, with special focus on appetite treatments. Neurosci Biobehav Rev. 2015;59:155-172.

24. M'Hamdi O, Ouertani I, Chaabouni-Bouhamed H. Update on the genetics of Bardet-Biedl syndrome. Mol Syndromol. 2014;5(2):51-56.

25. Forsythe E, Beales PL. Bardet-Biedl syndrome. Eur J Hum Genet. 2013;21(1):8-13

26. Brown JM, Witman GB. Cilia and diseases. Bioscience. 2014;64:1126-1137.

27. Seo S, Guo DF, Bugge K., Morgan DA, Rahmouni $\mathrm{K}$, SheffieldnVC. Requirement of Bardet-Biedl syndrome proteins for leptin receptor signaling. Hum Mol Genet. 2009;18(7):1323-1331.

28. Ristoska Bojkovska N, Spahiu L, Janchevska A, Gucev ZS, Tasic V. Renal dysplasia in Bardet-Biedl syndrome. Pril (Makedon Akad Nauk Umet Odd Med Nauki). 2015;36(1):211-215.

29. Marshall JD, Bronson RT, Collin GB, et al. New Alstrom syndrome phenotypes based on the evaluation of 182 cases. Arch Intern Med. 2005;165(6):675-683.

30. Pagon RA, Adam MP, Ardinger HH, et al., editors. Seattle (WA): University of Washington, Seattle; 1993-2017.

31. Collin GB, Marshall JD, Ikeda A, et al. Mutations in ALMS1 cause obesity, type 2 diabetes and neurosensory degeneration in Alstrom syndrome. Nat Genet. 2002;31(1):74-78.

32. Wang L, Shoemaker AH. Eating behaviors in obese children with pseudohypoparathyroidism type 1a: a cross-sectional study. Int J Pediatr Endocrinol. 2014;2014(1):21.

33. Turan S, Bastepe M. GNAS spectrum of disorders. Curr Osteoporos Rep. 2015;13(3):146-158.

34. Levine MA. An update on the clinical and molecular characteristics of pseudohypoparathyroidism. Curr Opi Endocrinol Diabetes Obes. 2012;19(6):443-451.

35. Rivera-Brugues N, Albrecht B, Wieczorek D, et al. Cohen syndrome diagnosis using whole genome arrays. J Med Genet. 2011;48(2):136-140.

36. Kolehmainen J, Black GC, Saarinen A, et al. Cohen syndrome is caused by mutations in a novel gene, $\mathrm{COH} 1$, encoding a transmembrane protein with a presumed role in vesicle-mediated sorting and intracellular protein transport. Am J Hum Genet. 2003;72(6):1359-1369.

37. Miyake N, Koshimizu E, Okamoto N, et al. MLL2 and KDM6A mutations in patients with Kabuki syndrome. Am J Med Genet. 2013;161A(9):22342243.

38. Ng SB, Bigham AW, Buckingham K.J et al. Exome sequencing identifies MLL2 mutations as a cause of Kabuki syndrome. Nat Genet. 2010;42(9):790793.

39. Lederer D, Grisart B, Digilio MC, et al. Deletion of KDM6A, a histone demethylase interacting with MLL2, in three patients with Kabuki syndrome. Am J Hum Genet. 2012;90(1):119-124.

40. Paulussen AD, Stegmann AP, Blok MJ, et al. MLL2 mutation spectrum in 45 patients with Kabuki syndrome. Hum Mutat. 2011;32(2):E2018-E2025.

41. Turner G, Lower KM, White SM, et al. The clinical picture of the Borjeson-Forssman-Lehmann syndrome in males and heterozygous females with PHF6 mutations. Clin Genet. 2004;65(3):226-232.

42. Lower KM, Turner G, Kerr BA, et al. Mutations in PHF6 are associated with Borjeson-Forssman-Lehmann syndrome. Nat Genet. 2002;32(4):661-665.

43. Cohen DM, Green JG, Miller J, Gorlin RJ, Reed JA. Acrocephalopolysyndactyly type II-Carpenter syndrome: clinical spectrum and an attempt at unification with Goodman and Summit syndromes. Am J Med Genet. 1987;28(2):311-324.

44. Alessandri JL, Dagoneau N, Laville JM, Baruteau J, Hebert JC, Cormier-Daire V. RAB23 mutation in a large family from Comoros Islands with Carpenter syndrome. Am J Med Genet. 2010;152A(4):982-986.

45. Jenkins D, Baynam G, Catte L. Carpenter syndrome: extended RAB23 mutation spectrum and analysis of nonsense-mediated mRNA decay. Hum Mutat. 2011;32(4):E2069-E2078.

46. Chen L, Mullegama SV, Alaimo JT, Elsea SH. Smith-Magenis syndrome and its circadian influence on development, behavior, and obesity - own experience. Dev Period Med. 2015;19(2):149-156.

47. Han JC, Liu QR, Jones M, Levinn RL, et al. Brain-derived neurotrophic factor and obesity in the WAGR syndrome. N Engl J Med. 2008;359(9):918-927.

48. Rodriguez-Lopez R, Perez JM, Balsera AM, et al. The modifier effect of the BDNF gene in the phenotype of the WAGRO syndrome. Gene. 2013;516(2):285-290.

49. Gucev Z, Muratovska O, Laban N,et al. Billateral polycystic kidneys in a girl with WAGR syndrome. Indian J Pediatr. 2011;78(10):1290-1292.

50. Montague CT, Farooqi IS, Whitehead JP, et al. Congenital leptin deficiency is associated with severe early-onset obesity in humans. Nature. 1997;387(6636):903-908.

51. Gibson WT, Farooqi IS, Moreau M, et al. Congenital leptin deficiency due to homozygosity for the 
Delta133G mutation: report of another case and evaluation of response to four years of leptin therapy. J Clin Endocrinol Metab. 2004;89(10):48214826.

52. Mazen I, El-Gammal M, Abdel-Hamid M, Amr $\mathrm{K}$. A novel homozygous missense mutation of the leptin gene (N103K) in an obese Egyptian patient. Mol Genet Metab. 2009;97(4):305-308.

53. Wabitsch M, Funcke JB, Lennerz B, et al. Biologically inactive leptin and early-onset extreme obesity. N Engl J Med. 2015;372:48-54.

54. Cl'ement K, Vaisse C, Lahlou N. A mutation in the human leptin receptor gene causes obesity and pituitary dysfunction. Nature. 1998;392(6674):398401.

55. Farooqi IS, Wangensteen T, Collins S. Clinical and molecular genetic spectrum of congenital deficiency of the leptin receptor. N Engl J Med. 2007;356(3):237-247.

56. Saeed S, Bonnefond A, Manzoor J, et al. Novel LEPR mutations in obese Pakistani children identified by PCR-based enrichment and next generation sequencing. Obesity. 2014;22(4):1112-1117.

57. Huvenne H, Beyec J, P'epin D, et al. Seven novel deleterious LEPR mutations found in early-onset obesity: a $\Delta$ Exon6-8 shared by subjects from Reunion Island, France, suggests a founder effect. J Clin Endocrinol Metab. 2015;100(5):E757-E66.

58. Farooqi, IS, Matarese G, Lord GM, et al. Beneficial effects of leptin on obesity, T cell hyporesponsiveness, and neuroendocrine/metabolic dysfunction of human congenital leptin deficiency. J Clin Invest. 2002;110(8):1093-1103.

59. Simonds SE, Pryor JT, Ravussin E, et al. Leptin mediates the increase in blood pressure associated with obesity. Cell. 2014;159(6):1404-1416.

60. Farooqi IS, Jebb SA, Langmack G, et al. Effects of recombinant leptin therapy in a child with congenital leptin deficiency. N Engl J Med. 1999;341:879884.

61. Doche ME, Bochukova EG, Su HW, et al. Human SH2B1 mutations are associated with maladaptive behaviors and obesity. J Clin Invest. 2012; 122(12):4732-4736.

62. Krude H, Biebermann H, Luck W, Horn R, Brabant G, Gruters A. Severe early-onset obesity, adrenal insufficiency and red hair pigmentation caused by POMC mutations in humans. Nat Genet. 1998;19(2):155-157.

63. Farooqi IS, Drop S, Clements A, et al. Heterozygosity for a POMC-null mutation and increased obesity risk in humans. Diabetes. 2006; 55(9):2549-2553.
64. Krude H, Biebermann H, Gruters A. Mutations in the human proopiomelanocortin gene. Ann N Y Acad Sci. 2003;994:233-239.

65. Ozen S, Ozcan N, Ucar SK, Goksen D, Darcan S. Unexpected clinical features in a female patient with proopiomelanocortin (POMC) deficiency. J Pediatr Endocrinol Metab. 2015;28(5-6):691-694.

66. Farooqi IS, Volders K, Stanhope R, et al. Hyperphagia and early-onset obesity due to a novel homozygous missense mutation in prohormone convertase 1/3. J Clin Endocrinol Metab. 2007;92(9):3369-3373.

67. Jackson RS, Creemers JW, Farooqi IS. Small-intestinal dysfunction accompanies the complex endocrinopathy of human proprotein convertase 1 deficiency. J Clin Invest. 2003:112(10):15501560.

68. Jackson RS, Creemers JW, Ohagi S, et al. Obesity and impaired prohormone processing associated with mutations in the human prohormone convertase 1 gene. Nat Genet. 1997;16(3):303-306

69. Frank GR., Fox J, Candela N, et al. Severe obesity and diabetes insipidus in a patient with PCSK1 deficiency. Mol Genet Metab. 2013;110(1-2):191194.

70. Martín MG, Lindberg I, Solorzano-Vargas RS, et al. Congenital Proprotein Convertase 1/3 Deficiency Causes Malabsorptive Diarrhea and other Endocrinopathies in a Pediatric Cohort. Gastroenterology. 2013;145(1):138-148.

71. Yourshaw M, Solorzano-Vargas RS, Pickett LA, et al. Exome Sequencing Finds a Novel PCSK1 Mutation in a Child With Generalized Malabsorptive Diarrhea and Diabetes Insipidus. J Pediatr Gastroenterol Nutr. 2013;57(6):759-767.

72. Philippe J, Stijnen P, Meyre D, et al. A nonsense loss-of-function mutation in PCSK1 contributes to dominantly inherited human obesity. Int J Obes. 2015;39(2):295-302.

73. Dubern B, Bisbis S, Talbaoui H, et al. Homozygous null mutation of the melanocortin-4 receptor and severe early-onset obesity. J Pediatr. 2007;150(6):613-617.e1.

74. Garg G, Kumar J, McGuigan FE, et al. Variation in the MC4R Gene Is Associated with Bone Phenotypes in Elderly Swedish Women. Devaney J, ed. PLoS One. 2014;9(2):e88565.

75. Timpson NJ, Sayers A, Davey-Smith G, Tobias $\mathrm{JH}$. How does body fat influence bone mass in childhood? A Mendelian randomization approach. J Bone Miner Res. 2009;24(3):522-533.

76. Farooqi IS, Yeo GS, Keogh JM, et al. Dominant andrecessive inheritance of morbid obesity associated with melanocortin 4 receptor deficiency. $\mathrm{J}$ Clin Invest. 2000;106(2):271-279. 
77. Farooqi IS, Keogh JM, Yeo GS, Lank EJ, Cheetham T, O'Rahilly S. Clinical spectrum of obesity and mutations in the melanocortin 4 receptor gene. N Engl J Med. 2003;348(12):1085-1095.

78. Yeo GS, Conie Hung CC, Rochford, J, et al. A de novo mutation affecting human TrkB associated with severe obesity and developmental delay. Nat Neurosci. 2004;7(11):1187-1189.

79. Gray J, Yeo GS, Cox JJ, et al. Hyperphagia, severe obesity, impaired cognitiven function, and hyperactivity associated with functional loss of one copy of the brain-derived neurotrophic factor (BDNF) gene. Diabetes. 2006;55(12):3366-3371.

80. Michaud JL, DeRossi C, May NR, Holdener BC, Fan CM. ARNT2 acts as the dimerization partner of SIM1 for the development of the hypothalamus. Mech Dev. 2000;90(2):253-261.

81. Michaud JL, Rosenquist T, May NR, Fan CM. Development of neuroendocrine lineages requires the bHLH-PAS transcription factor SIM1. Genes Dev. 1998;12(20):3264-3275.

82. Michaud JL, Boucher F, Melnyk A. Sim1 haploinsufficiency causes hyperphagia, obesity and reduction of the paraventricular nucleus of the hypothalamus. Hum Mol Genet. 2001;10(14): 1465-1473.

83. Holder JL, Butte NF, Zinn AR. Profound obesity associated with a balanced translocation that disrupts the SIM1 gene. Hum Mol Genet. 2000;9:101-108.

84. Bonnefond A, Raimondo A, Stutzmann F, et al. Loss-of-function mutations in SIM1 contribute to obesity and Prader-Willi-like features . J Clin Invest. 2013;123(7):3037-3041.

85. Montagne L, Raimondo A, Delobel B, et al. Identification of two novel loss-of-function SIM1 mutations in two overweight children with developmental delay. Obesity. 2014;22(12):2621-2624.

86. Ramachandrappa S, Raimondo A, Cali AMG, et al. Rare variants in single-minded 1 (SIM1) are associated with severe obesity . J Clin Invest. 2013;123(7):3042-3050.

87. Pearce LR, Atanassova N, Banton MC, et al. KSR2 Mutations Are Associated with Obesity, Insulin Resistance, and Impaired Cellular Fuel Oxidation. Cell. 2013;155(4):765-777.

88. Borman AD, Pearce LR, Mackay DS, et al. A Homozygous Mutation in the TUB Gene Associated with Retinal Dystrophy and Obesity. Hum Mutat. 2014;35(3):289-293.

89. Choquet H, Meyre D. Molecular Basis of Obesity: Current Status and Future Prospects. Curr Genomics. 2011;12(3):154-168.
90. Choquet H, Meyre D. Genetics of Obesity: What have we Learned? Curr Genomics. 2011;12(3):169179.

91. Stutzmann F, Tan K, Vatin V, et al. Prevalence of melanocortin-4 receptor deficiency in Europeans and their age-dependent penetrance in multigenerational pedigrees. Diabetes. 2008;57(9):25112518.

92. Stanikova D, Surova M, Buzga M, et al. Age of obesity onset in MC4R mutation carriers. Endocr Regul. 2014;49(3):137-140.

93. Biebermann H, Castaneda TR, van Landeghem F, et al. A role for $\beta$-melanocyte-stimulating hormone in human body-weight regulation. Cell Metab. 2006;3(2):141-146.

94. Challis BG, Pritchard LE, Creemers JW, et al. A missense mutation disrupting a dibasic prohormone processing site in pro-opiomelanocortin (POMC) increases susceptibility to early-onset obesity through a novel molecular mechanism. Hum Mol Genet. 2002;11(17):1997-2004.

95. Lee YS, Challis BG, Thompson DA, et al. A POMC variant implicates $\beta$-melanocyte-stimulating hormone in the control of human energy balance. Cell Metab. 2006;3(2):135-140.

96. Farooqi IS, Keogh JM, Kamath S, et al. Metabolism: partial leptin deficiency and human adiposity. Nature. 2001;414(6859):34-35.

97. Cummings DE, Schwartz MW. Genetics and pathophysiology of human obesity. Annu Rev Med. 2003;54:453-471.

98. Meyre D, Bouatia-Naji N, Tounian A, et al. Variants of ENPP1 are associated with childhood and adult obesity and increase the risk of glucose intolerance and type 2 diabetes. Nat Genet. 2005;37(8):863-867.

99. Meyre D, Lecoeur C, Delplanque J, et al. A genome-wide scan for childhood obesity-associated traits in French families shows significant linkage on chromosome 6q22.31-q23.2. Diabetes. 2004;53(3):803-811.

100. Wang R, Zhou D, Xi B, et al. ENPP1/PC-1 gene $\mathrm{K} 121 \mathrm{Q}$ polymorphism is associated with obesity in European adult populations: evidence from a meta-analysis involving 24,324 subjects. Biomed Environ Sci. 2011;24(2):200-206.

101. Warrington NM, Howe LD, Paternoster L, et al. A genome-wide association study of body mass index across early life and childhood. Int J Epidemiol. 2015;44(2):700-712.

102. Bradfield JP, Taal HR, Timpson NJ, et al. A genome-wide association meta-analysis identifies new childhood obesity loci. Nat Genet. 2012;44(5):526-531. 
103.Locke AE, Kahali B, Berndt SI, et al. Genetic studies of body mass index yield new insights for obesity biology. Nature. 2015;518(7538):197-206.

104. Meyre D, Delplanque J, Chevre JC, et al. Genome-wide association study for early-onset and morbid adult obesity identifies three new risk loci in European populations. Nat Genet. 2009;41(2):157-159.

105.Li A, Meyre D. Jumping on the Train of Personalized Medicine: A Primer for Non- Geneticist Clinicians: Part 3. Clinical Applications in the Personalized Medicine Area. Curr Psychiatry Rev. 2014;10(2):118-132.

106. Bonnefond A, Philippe J, Durand E, et al. Highly sensitive diagnosis of 43 monogenic forms of diabetes or obesity through one-step PCR-based enrichment in combination with next-generation sequencing. Diabetes Care. 2014;37(2):460-467.

107.Philippe J, Derhourhi M, Durand E, et al. What Is the Best NGS Enrichment Method for the Molecular Diagnosis of Monogenic Diabetes and Obesity? Brusgaard K, ed. PLoS One. 2015;10(11):e0143373.

108. Hinney A, Wolters B, Pütter C, et al. J Pediatr Endocrinol Metab. 2013;26(11-12):1209-1213.

109. Reinehr T, Wolters B, Roth CL, Hinney A. (2014) FTO gene: association to weight regain after lifestyle intervention in overweight children. Horm Res Paediatr. 2014;81(6):391-396.

110. Qi L. Gene-diet interaction and weight loss. Curr Opinion Lipid. 2014;25(1):27-34.

111. Le Beyec J, Cugnet-Anceau C, Pepin D, et al. Homozygous leptin receptor mutation due to uniparental disomy of chromosome 1: response to bariatric surgery. J Clin Endocrinol Metab. 2013;98(2):E397-E402.

112. Aslan IR, Campos GM, Calton MA, Evans DS, Merriman RB, Vaisse C. Weight Loss after Roux-en-Y Gastric Bypass in Obese Patients Heterozygous for MC4R Mutations. Obes Surg. 2011;21(7):930-934.

113. Hatoum IJ, Stylopoulos N, Vanhoose AM, et al. Melanocortin-4 Receptor Signaling Is Required for Weight Loss after Gastric Bypass Surgery. J Clin Endocrinol Metabol. 2012;97(6):E1023-E1031.

114. Valette M, Poitou C, Le Beyec J, Bouillot J-L, Clement K, Czernichow S. Melanocortin-4 Receptor Mutations and Polymorphisms Do Not Affect Weight Loss after Bariatric Surgery. Folli F, ed. PLoS One. 2012;7(11):e48221.

115. Meyre D, Froguel P, Horber FF, Kral JG. Comment On: Valette et al. Melanocortin-4 Receptor Mutations and Polymorphisms Do Not Affect Weight Loss after Bariatric Surgery. PLoS
One. 2012;7(11):E48221. Folli F, ed. PLoS One. 2014;9(3):e93324.

116. Moore BS, Mirshahi UL, Yost EA, et al. LongTerm Weight-Loss in Gastric Bypass Patients Carrying Melanocortin 4 Receptor Variants. López M, ed. PLoS One. 2014;9(4):e93629.

117. Sarzynski MA, Jacobson P, Rankinen, T, et al. Associations of markers in 11 obesity candidate genes withmaximal weight loss and weight regain in the SOS bariatric surgery cases. Int J Obes. 2011;35(5):676-683.

118. Hatoum IJ, Greenawalt DM, Cotsapas C, Daly MJ, Reitman ML, Kaplan LM. Weight Loss after Gastric Bypass Is Associated with a Variant at 15q26.1. Am J Hum Genet. 2013;92(5):827-834.

119. Fujioka K. Safety and tolerability of medications approved for chronic weight management. Obesity. 2015;23(Suppl 1):S7-S11.

120. Lazary J, Juhasz G, Hunyady L, Bagdy G. Personalized medicine can pave the way for the safe use of CB(1) receptor antagonists. Trends Pharmacol Sci. 2011;32(5):270-280.

121.Bjorge T, Engeland A, Tverdal A, Smith GD. Body mass index in adolescence in relation to cause-specifi c mortality: a follow-up of 230,000 Norwegian adolescents. Am J Epidemiol. 2008;168(1):30-37.

122. Gordon JE, Hughes MS, Shepherd K, et al. Obstructive sleep apnoea syndrome in morbidly obese children with tibia vara. J Bone Joint Surg Br. 2006;88(1):100-103.

123. Murray AW, Wilson NI. Changing incidence of slipped capital femoral epiphysis: a relationship with obesity? J Bone Joint Surg Br. 2008;90(1):9294.

124. Timpson NJ, Sayers A, Davey-Smith G, Tobias $\mathrm{JH}$. How does body fat infl uence bone mass in childhood? A Mendelian randomization approach. J Bone Miner Res. 2009;24(3):522-533.

125. Tirosh A, Shai I, Afek A, Dubnov-Raz G, et al. Adolescent BMI trajectory and risk of diabetes versus coronary disease. N Engl J Med. 2011;364(14):1315-1325.

126. Ogden CL, Carroll MD, Kit BK, Flegal KM. Prevalence of obesity and trends in body mass index among US children and adolescents, 1999-2010. JAMA. 2012;307(5):483-490.

127. Calcaterra V, Klersy C, Muratori T, et al. Prevalence of metabolic syndrome (MS) in children and adolescents with varying degrees of obesity. Clin Endocrinol (Oxf). 2008;68(6):868-872.

128. Rosenfield RL, Lipton RB, Drum ML. Thelarche, pubarche, and menarche attainment in children with normal and elevated body mass index. Pediatrics. 2009;123(1):84-88. 
129. Bau AM, Ernert A, Schenk L, et al. Is there a further acceleration in the age at onset of menarche? A cross-sectional study in 1840 school children focusing on age and bodyweight at the onset of menarche. Eur J Endocrinol. 2009;160(1):107113.

130. Mamun AA, Hayatbakhsh MR, O'Callaghan M, Williams G, Najman J. Early overweight and pubertal maturation - pathways of association with young adults' overweight: a longitudinal study. Int J Obes (Lond). 2009;33(1):14-20.

131. Denzer C, Weibel A, Muche R, Karges B, Sorgo W, Wabitsch M. Pubertal development in obese children and adolescents. Int J Obes (Lond). 2007;31(10):1509-1519.

132. Taylor ED, Theim KR, Mirch MC, et al. Orthopedic complications of overweight in children and adolescents. Pediatrics. 2006; 117(6):2167-2174.

133. DiVall SA, Radovick S. Endocrinology of female puberty. Curr Opin Endocrinol Diabetes Obes. 2009;16(1):1-4.

134.Coffield JE, Metos JM, Utz RL, Waitzman NJ. A multivariate analysis of federally mandated school wellness policies on adolescent obesity. J Adolesc Health. 2011;49(4):363-70.

135. Kalarchian MA, Levine MD, Arslanian SA, et al. Family-based treatment of severe pediatric obesity: randomized, controlled trial. Pediatrics. 2009;124(4):1060-1068.

136. Ortega FB, Labayen I, Ruiz JR, et al. Improvements in fitness reduce the risk of becoming overweight across puberty. Med Sci Sports Exerc. 2011;43(10):1891-1897.

137. Chang S-H, Stoll CRT, Song J, Varela E, Eagon CJ, Colditz G a. Bariatric surgery: an updated systematic review and meta analysis, 2003-2012. JAMA Surg. 2014;149(3):275-287.

138. Cummings DE, Overduin J, Foster-Schubert KE. Gastric Bypass for Obesity : Mechanisms of Weight Loss and Diabetes Resolution. J Clin Endocrinol Metab. 2015;89(6):2608-2615.

139. Chapman AE, Hons BA, Kiroff G, Game P. Clinical review Laparoscopic adjustable gastric banding in the treatment of obesity : A systematic literature review. Surgery. 2004;153(3):326-351. 
Резиме

\title{
ОБЕЗНОСТА ВО ДЕТСТВОТО И АДОЛЕСЦЕНЦИЈАТА, ГЕНЕТСКИ ФАКТОРИ
}

\author{
Марко Костовски ${ }^{1}$, Велибор Тасиќ ${ }^{1}$, Невена Лабан ${ }^{1}$, \\ Момир Поленаковиќ ${ }^{2}$, Драган Даниловски ${ }^{1}$, Зоран Гучев ${ }^{1}$ \\ ${ }^{1}$ Медицински факултет, Универзитет „Св. Кирил и Методиј“, \\ 50 Дивизија бб, 1000 Скопје, Република Македонија \\ ${ }^{2}$ Македонска академија на науките и уметностите, Скопје, Република Македонија
}

Обезноста и прекумерната тежина се пандемски феномени во модерниот свет. Адултната обезност често е резултат на обезноста во детството и во адолесценцијата. Трошоците поврзани со обезноста и компликациите што произлегуваат од неа се запрепастувачки, особено за земјите во развој. Обезноста во детството е, исто така, широко распространета и во Македонија. Метаболниот синдром, дислипидемијата и јаглехидратната интолеранција се присутни во значителен број. Родителите, бабите и дедовците се често со обезност. Некои од децата се или дизморфични или со благо заостанување во менталниот развој, како што ги имаме веќе опишано кај синдромите на Prader-Willi, Bardet-Biedl или WAGR.

Генетскиот скрининг за мутации за моногенетската обезност кај децата со ран и брз почеток на обезноста, односно екстремна обезност, тешка хиперфагија, хипогонадизам, интестинална дисфункција, хипопигментација на косата или кожата, постпрандијална хипогликемија, инсипиден дијабет, абнормални нивоа на лептин и постоење браќа и сестри со обезност или посно тело во семејството, открива многу форми на обезност.

Дополнително, како што обезноста покажува разлики во различни етнички групи така и типовите на моногенетска обезност се разликуваат. Накратко, сѐ поголем број гени и генетски механизми сѐ уште се откриваат кај децата. Ова отвора нови порти во молекуларните механизми на обезноста и дава нови потенцијални форми на третман.

Клучни зборови: обезитет, деца, адолесценти, генетски причини 